\title{
Performance and Stability Analysis of Several Yellow Maize Hybrids
}

\author{
Kh. A. M. Ibrahim
}

Department of Agronomy, Faculty of Agriculture, Assuit University, New Valley, Egypt

Email:kh_ibrahim75@aun.edu.eg

\begin{abstract}
:
Performance and stability of 13 maize single cross hybrids were estimated under five different environments in Egypt during 2013 summer season. A randomized complete block design was used at each environment. Mean squares due to environments, Genotypes and $\mathrm{G} \times \mathrm{E}$ interaction were highly significant for grain yield and other agronomic traits. Based on combined data $\mathrm{H} 2$ possessed the highest grain yield $(5.15 \mathrm{~kg} / \mathrm{plot})$ and significantly outyielded the check hybrid H13 (4.59 kg/plot). According to stability analysis the G x E (linear) interaction was not significant and had low portion of the $\mathrm{G} \times \mathrm{E}$ interaction when compared to the environment linear mean of squares for grain yield and the other studied. If the mean yield $(\overline{\mathrm{X}})$, regression coefficient value $\left(\mathrm{b}_{\mathrm{i}}\right)$ and the deviation from the regression $\left(S_{\mathrm{di}}^{2}\right)$ are considered together, then the most stable hybrid would be H2 and H9. The most stable hybrids according to the ecovalence method were H10, H8, H1, H9. These hybrids were not the best ranked for grain yield, except $\mathrm{H}$, which possessed the first rank for grain yield with $5.15 \mathrm{~kg}_{\text {plote }}{ }^{-1}$ (Plot size is $9.6 \mathrm{~m}^{2}$ ) and is considered as a promising hybrid for stability.
\end{abstract}

Keyword: stability, maize, grain yield

Received on: $21 / 6 / 2015$

Accepted for publication on: 5/7/2015

Referees: Prof. Adel M. Mahmoud

Prof. Adel S. Taghian 


\section{Introduction:}

Maize (Zea mays L.) is one of the most important cereal crops. Its cultivation extends over a wide range of geographical and environmental conditions ranging from $58^{\circ} \mathrm{N}$ to $40^{\circ} \mathrm{S}$. Maize has been subjected to extensive genetic studies than any other crops (Hallauer and Miranda 1988). Plant breeders are interested in hybrids that are not affected much by environmental variations. Some hybrids give the best performance at special environment. Evaluation of these hybrids on the average basis over different environments would underestimate the productivity of such hybrids when were grown at their favorable environments.

The successful new maize hybrids must exhibit high performance for grain yield and other agronomic traits. Moreover, their superiority should be stable over a wide range of environmental conditions. The choice of suitable hybrids is subject to two considerations, high grain yield over a wide range of environment, and stable performance over different environments. Consistency of performance is depending upon the genotype $\mathrm{x}$ environment interaction $(\mathrm{G} \times \mathrm{E})$. Hybrids, which have small $\mathrm{G} \times \mathrm{E}$ interaction are consider more stable. Stability of yield is defined as the ability of genotype to avoid substantial fluctuations in yield over a range of environments (Heinrich et al. 1983).

Stability analysis provides general information of the response patterns of genotypes to environmental changes. The main type of stability analysis, termed joint re- gression analysis (Freeman 1973), involves the regression of genotype means on an environmental index. The regression coefficient $\left(b_{i}\right)$ for each genotype is considering a measure of stability. A b-value close to 1.0 pointed to average stability, genotypes with $b_{i}=1.0$ and high mean yield are consider have general adaptation, while a genotype with $b_{i}=1.0$ and low average yield is consider poor adaptation to all environments. In addition to regression coefficient Eberhart and Russell (1966) estimated the mean square of deviation from the regression as another stability parameters.

The regression coefficient and the deviation from regression describe the performance of a hybrid over different environments. The regression coefficient measure the increase of response of a hybrid per unit of environment index, whereas the deviations from regression measure the agreement between predicted and observed response. A high yielding hybrid with $b_{i}=1.0$ or below indicated that the hybrid possessed high stability over all environments. The most stable hybrid would be have $b_{i}=1$ with low deviation from regression $\left(S_{\mathrm{di}}^{2}\right)$.

Wricke (1962) proposed using the $G \times E$ interaction effect for each genotype, squared and summed over all environments, as a stability measure. This statistic, termed ecovalence $\left(\mathrm{W}_{\mathrm{i}}\right)$ is far more simple to estimate and more directly related to the $\mathrm{G} \times \mathrm{E}$ interactions. Because ecovalence measures the contribution of a genotype to the $\mathrm{G} \times \mathrm{E}$ interaction a genotype with $\mathrm{W}_{\mathrm{i}}=0$ is 
consider stable. Stable genotype give a high ecovalence (low values of $\mathrm{W}_{\mathrm{i}}=$ high ecovalence).

The objective of this study was to estimate performance and stability of 13 yellow maize single crosses for number of days to $50 \%$ silking, plant and ear height and grain yield.

\section{Materials and Methods:}

Eleven new single cross hybrids of yellow maize were pro- duced in 2012 growing season at Sakha, Gemmeiza and mallawy Agricultural Research Stations, Agricultural Research Center (ARC). The produced 11 hybrids along with two check hybrids were evaluated in 2013 growing season at five locations namely, Sakha $\left(\mathrm{E}_{1}\right)$, Gemmeiza $\left(\mathrm{E}_{2}\right)$, Sids $\left(\mathrm{E}_{3}\right)$, Mallawy $\left(\mathrm{E}_{4}\right)$ and Nubaria $\left(\mathrm{E}_{5}\right)$ Agricultural Research Stations. Hybrids which used in this study are shown in Table 1.

Table (1): Abbreviation of hybrids which used in this investigation.

\begin{tabular}{|c|c|c|c|}
\hline Hybrid name & No. & Hybrid name & No. \\
\hline Sk-179 & H1 & Mall 146 & H8 \\
\hline Sk-180 & H2 & SC 01 & H9 \\
\hline Gm-1 & H3 & SC 02 & H10 \\
\hline Mall-125 & H4 & SC 03 & H11 \\
\hline Mall-133 & H5 & SC Gz 162 (check) & H12 \\
\hline Mall-142 & H6 & SC Gz 166 (check) & H13 \\
\hline Mall 144 & H7 & - & - \\
\hline
\end{tabular}

Randomized complete block design with four replications was used. Each plot consisted of four rows of $6.0 \mathrm{~m}$ long and $0.8 \mathrm{~m}$ apart (plot size was $9.6 \mathrm{~m}^{2}$ ). Planting date at all locations was during the second half of May, planting was done in hills spaced $0.25 \mathrm{~m}$ along the row. The plants were thinned to one plant per hill before the first irrigation. All other cultural practice for maize production were applied as recommended.

Harvested ears from two inner rows were weighed and five $\mathrm{kg}$ from each plot were taken for measuring moisture percentage. Grain yield was adjusted to $15.5 \%$ moisture content and recorded in $\mathrm{kg}$ $\mathrm{plot}^{-1}$. Data were recorded for number of days to $50 \%$ silking, plant height $(\mathrm{cm})$, ear height $(\mathrm{cm})$ and ad- justed grain yield in $\mathrm{kg} \mathrm{plot}^{-1}$. Data for all studied traits of each single environment and combined over environments were statistically analyzed according to Steel and Torrie (1980).

Stability parameters was performed according to the following approach.

1- Regression coefficient $\left(b_{i}\right)$ and deviation mean squares $\left(\mathrm{S}_{\mathrm{di}}^{2}\right)$ according to Eberhart and Russell (1966). The $\mathrm{G} \times \mathrm{E}$ is portioned into a components due to linear regression $\left(b_{i}\right)$ at the $i^{\text {th }}$ genotype on the environment mean, and deviation $\left(\mathrm{d}_{\mathrm{ij}}\right)$.

$$
\begin{aligned}
& (G E)_{i j}=b_{i} E_{j}+d_{i j} \\
& \text { and thus: } \\
& Y_{i j}=\mu+G_{i}+E_{j}+\left(b_{i} E_{j}+d_{i j}\right)+e_{i j} \\
& \text { 2- Ecovalence }\left(W_{i}\right) \text { according }
\end{aligned}
$$
to Wricke (1962), defined the con- 
cept of ecovalence as contribution of each genotype to the GxE sum of squares. The ecovalence $\left(\mathrm{W}_{\mathrm{i}}\right)$ is express as:

$$
\mathbf{W}_{\mathrm{i}}=\sum\left(\overline{\mathrm{Y}}_{\mathrm{ij}}-\overline{\mathrm{Y}}_{\mathrm{i}}-\overline{\mathrm{Y}}_{\mathrm{j}}+\overline{\mathrm{Y}}_{\mathrm{.}}\right)^{2}
$$

Where:

$\overline{\mathbf{Y}}_{\mathrm{ij}}$ is the mean performance of genotype $\mathbf{i}^{\text {th }}$ in the $\mathbf{j}^{\text {th }}$ environment and $\overline{\mathbf{Y}}_{\mathbf{i} \text {. }}$ and $\overline{\mathbf{Y}}_{\mathrm{j}}$ are the genotype and environment mean deviation, respectively and $\overline{\mathbf{Y}}$ is the over all mean. For this reason, genotypes with a low $\mathrm{W}_{\mathrm{i}}$ value have smaller deviations from the mean across environments and are thus more stable.

\section{Results and Discussion:}

Hybrids performance, environmental index (E. index) and phenotypic index for all traits are presented in Tables 2 and 3. Because the environmental index was calculated as the difference between the environment mean and the mean across all environments, it is directly reflects the rich or poor environment in term of positive and negative, respectively. Hence, E1 was the most favorable environment, which was linked to be the highest mean grain yield $(5.12 \mathrm{~kg}$ plot $^{-1}$, while E5 was the poorest yielding environment $\left(3.50 \mathrm{~kg} \mathrm{plot}^{-}\right.$ $\left.{ }^{1}\right)$.

Data in Table 2 and 3 showed that the best hybrids for plant height and ear height toward shortness and low ear height were $\mathrm{H} 3, \mathrm{H} 4, \mathrm{H} 6$ and $\mathrm{H} 8$ and are considered a good hy- brids for shortness and low ear placement.

Data in Table 3 showed that grain yield varied from 2.96 to 6.36 $\mathrm{kg} /$ plot for $\mathrm{H} 8$ at E5 and $\mathrm{H} 2$ at E1, respectively. Based on combined data over all environments, $\mathrm{H} 2$ possessed the highest grain yield (5.15 $\mathrm{kg} / \mathrm{plot}$ ) and significantly outyielded the commercial check hybrid H13 $(4.59 \mathrm{~kg} /$ plot). Moreover, 5 hybrids (H4, H5, H7, H9 and H11) gave high grain yield and did not significantly outyilded of the best check hybrid (H13), three of them namely, $\mathrm{H} 4, \mathrm{H} 5, \mathrm{H} 7$ also were significantly earlier than the check hybrid H13.

Mean squares due to environments, Genotypes and G x E interactions were highly significant $(\mathrm{P}<$ 0.01 ) for number of days to $50 \%$ silking, plant height, ear height and grain yield (Table 4). This could be due to presence of substantial variation of the mean performance of all the 13 hybrids across environments and in the environmental mean over the evaluated hybrids.

Significant $G \times \mathrm{E}$ interaction variance is suggestive of differential performance of the evaluated hybrids under different environments. In this respect, Eberhart and Russell (1966), Freeman and Perkins (1971), Ibrahim et al (1984), Ragheb et al (1993), Soliman (2006) and Abd El-Moula (2011), stated that the basic cause of the differences among hybrids in their yield stability is the wide occurrence of hybrid $\mathrm{x}$ environment $(\mathrm{G} x$ E) interaction. 
Table (2): Mean performance for number of days to $50 \%$ silking and plant height $(\mathrm{cm})$ of 13 single cross hybrids evaluated at 5 different environments, 2013 growing season.

\begin{tabular}{|c|c|c|c|c|c|c|c|c|c|c|c|c|c|c|}
\hline \multirow[b]{2}{*}{ Hybrid } & \multicolumn{7}{|c|}{ Number of days to $50 \%$ silking } & \multicolumn{7}{|c|}{ Plant height (cm) } \\
\hline & E1 & E2 & $\mathbf{E 3}$ & E4 & E5 & Mean & $\begin{array}{l}\text { Pheno } \\
\text { Index }\end{array}$ & E1 & E2 & $\mathbf{E 3}$ & $\mathbf{E} 4$ & $\mathbf{E 5}$ & Mean & $\begin{array}{l}\text { Pheno. } \\
\text { Index }\end{array}$ \\
\hline H1 & 64.75 & 65.75 & 62.25 & 65.25 & 63.50 & 64.30 & 3.53 & 310.00 & 242.50 & 263.75 & 5250.25 & 226.50 & 258.60 & 12.35 \\
\hline H2 & 65.25 & 66.00 & 64.50 & 65.75 & 63.50 & 65.00 & 4.23 & 302.75 & 292.50 & 311.25 & 5255.50 & 267.00 & 285.80 & 39.55 \\
\hline H3 & 61.75 & 62.75 & 59.50 & 60.00 & 58.00 & 60.40 & -0.37 & 237.25 & 238.75 & 243.7 & 5230.00 & 225.25 & 235.00 & -11.25 \\
\hline H4 & 57.75 & 58.75 & 56.50 & 56.75 & 56.75 & 57.30 & -3.47 & 261.00 & 215.00 & 251.25 & 230.50 & 209.25 & 233.40 & -12.85 \\
\hline H5 & 58.25 & 59.00 & 56.75 & 56.75 & 56.75 & 57.50 & -3.27 & 284.75 & 243.75 & 285.00 & 245.50 & 252.75 & 262.35 & 16.10 \\
\hline H6 & 60.25 & 58.75 & 56.25 & 57.00 & 57.75 & 58.00 & -2.77 & 242.00 & 205.00 & 245.00 & 221.75 & 208.75 & 224.50 & -21.75 \\
\hline H7 & 58.75 & 59.25 & 55.50 & 57.00 & 57.00 & 57.50 & -3.27 & 283.75 & 243.75 & 280.00 & 247.50 & 230.00 & 257.00 & 10.75 \\
\hline H8 & 57.50 & 58.50 & 55.00 & 55.75 & 55.25 & 56.40 & -4.37 & 245.00 & 212.50 & 236.25 & 5227.00 & 203.00 & 224.75 & -21.50 \\
\hline H9 & 62.25 & 62.75 & 59.75 & 62.75 & 60.25 & 61.55 & 0.78 & 252.75 & 210.00 & 260.00 & 238.75 & 195.25 & 231.35 & -14.90 \\
\hline H10 & 64.25 & 64.25 & 59.25 & 62.25 & 63.25 & 62.65 & 1.88 & 268.25 & 235.00 & 265.00 & 253.25 & 223.75 & 249.05 & 2.80 \\
\hline H11 & 64.25 & 62.75 & 59.75 & 64.75 & 61.25 & 62.55 & 1.78 & 253.00 & 222.50 & 247.50 & 234.75 & 212.25 & 234.00 & -12.25 \\
\hline H12 & 64.75 & 65.50 & 62.25 & 65.25 & 63.75 & 64.30 & 3.53 & 292.00 & 255.00 & 292.50 & 251.75 & 237.00 & 265.65 & 19.40 \\
\hline H13 & 63.75 & 62.50 & 61.50 & 63.50 & 61.50 & 62.55 & 1.78 & 273.25 & 218.75 & 263.75 & 233.50 & 210.00 & 239.85 & -6.40 \\
\hline $\begin{array}{l}\text { Mean } \\
(\overline{\mathrm{X}})\end{array}$ & 61.81 & 62.04 & 59.13 & 60.98 & 59.88 & 60.77 & - & 269.67 & 233.46 & 265.00 & 240.00 & 223.13 & 246.25 & - \\
\hline $\mathrm{CV}$ & 2.07 & 1.47 & 2.48 & 2.10 & 1.53 & 1.96 & - & 4.99 & 5.07 & 4.03 & 5.03 & 5.52 & 4.91 & - \\
\hline $\mathbf{L S D}_{0.05}$ & 1.78 & 1.27 & 2.03 & \begin{tabular}{|l|}
1.77 \\
\end{tabular} & 1.27 & 1.65 & - & 18.64 & 16.36 & 14.79 & 16.73 & 17.08 & 16.77 & - \\
\hline E. index & 1.04 & 1.27 & -1.64 & 0.21 & -0.89 & - & - & 23.42 & -12.79 & 18.75 & -6.25 & -23.12 & - & - \\
\hline
\end{tabular}


Table (3): Mean performance for ear height and grain yield $\left(\mathrm{kg} \mathrm{plot}^{-1}\right)$ of 13 single cross hybrids evaluated at 5 different environments, 2013 growing season.

\begin{tabular}{|c|c|c|c|c|c|c|c|c|c|c|c|c|c|c|}
\hline \multirow[b]{2}{*}{ Hybrid } & \multicolumn{7}{|c|}{ Ear height (cm) } & \multicolumn{7}{|c|}{ Grain yield $\left(\mathrm{kg} \mathrm{plot}^{-1}\right)$} \\
\hline & E1 & E2 & $\mathbf{E 3}$ & E4 & E5 & Mean & $\begin{array}{l}\text { Pheno. } \\
\text { Index }\end{array}$ & E1 & E2 & E3 & E4 & $\mathbf{E 5}$ & Mean & $\begin{array}{l}\text { Pheno. } \\
\text { Index }\end{array}$ \\
\hline H1 & 175.25 & 148.75 & 145.00 & 135.50 & 133.25 & 147.55 & 13.80 & 4.96 & 3.32 & 4.16 & 3.82 & 3.64 & 3.98 & -0.29 \\
\hline H2 & 187.25 & 165.00 & 166.25 & 140.25 & 123.00 & 156.35 & 22.60 & 6.36 & 5.02 & 5.08 & 5.10 & 4.21 & 5.15 & 0.88 \\
\hline H3 & 130.50 & 137.50 & 120.00 & 120.25 & 115.00 & 124.65 & -9.10 & 3.63 & 3.47 & 3.27 & 2.84 & 3.18 & 3.28 & -0.99 \\
\hline H4 & 133.50 & 118.75 & 122.50 & 118.25 & 92.25 & 117.05 & -16.70 & 5.36 & 2.84 & 4.66 & 4.83 & 3.61 & 4.26 & -0.01 \\
\hline H5 & 156.00 & 140.00 & 138.75 & 131.50 & 122.75 & 137.80 & 4.05 & 5.19 & 3.03 & 4.46 & 5.02 & 3.51 & 4.24 & -0.03 \\
\hline H6 & 128.25 & 133.75 & 112.50 & 110.75 & 96.25 & 116.30 & -17.45 & 4.23 & 3.76 & 4.40 & 4.64 & 3.39 & 4.08 & -0.19 \\
\hline H7 & 152.25 & 132.50 & 136.25 & 131.75 & 108.25 & 132.20 & -1.55 & 5.75 & 3.48 & 4.95 & 5.45 & 3.40 & 4.61 & 0.34 \\
\hline H8 & 127.75 & 117.50 & 118.75 & 115.75 & 98.00 & 115.55 & -18.20 & 4.52 & 3.41 & 4.09 & 4.50 & 2.96 & 3.90 & -0.37 \\
\hline H9 & 145.25 & 128.75 & 133.75 & 130.25 & 104.75 & 128.55 & -5.20 & 5.37 & 4.14 & 5.40 & 5.02 & 3.52 & 4.69 & 0.42 \\
\hline H10 & 152.75 & 146.25 & 140.00 & 137.25 & 119.75 & 139.20 & 5.45 & 4.85 & 3.26 & 4.62 & 4.32 & 3.24 & 4.06 & -0.21 \\
\hline H11 & 154.50 & 141.25 & 140.00 & 126.25 & 121.00 & 136.60 & 2.85 & 4.68 & 4.07 & 4.52 & 4.23 & 3.70 & 4.24 & -0.03 \\
\hline H12 & 160.50 & 156.25 & 158.75 & 140.25 & 118.25 & 146.80 & 13.05 & 5.58 & 4.10 & 5.11 & 4.19 & 3.29 & 4.45 & 0.18 \\
\hline H13 & 162.25 & 147.50 & 146.25 & 127.50 & 116.75 & 140.05 & 6.30 & 6.04 & 3.84 & 5.19 & 4.09 & 3.79 & 4.59 & 0.32 \\
\hline $\begin{array}{l}\text { Mean } \\
(\overline{\mathrm{X}})\end{array}$ & 151.27 & 139.52 & 136.83 & 128.12 & 113.02 & 133.75 & - & 5.12 & 3.67 & 4.61 & 4.47 & 3.50 & 4.27 & - \\
\hline $\mathrm{CV}$ & 4.52 & 6.54 & 4.20 & 7.28 & 8.04 & 7.41 & - & 8.48 & 6.44 & 6.40 & 7.61 & 9.31 & 7.90 & - \\
\hline $\mathbf{L S D}_{\mathbf{0 . 0 5}}$ & 9.48 & 11.61 & 7.97 & 12.92 & 12.60 & 13.74 & - & 0.63 & 0.33 & 0.41 & 0.47 & 0.45 & 0.46 & - \\
\hline E. index & 17.52 & 5.77 & 3.08 & -5.63 & -20.73 & - & - & 0.85 & -0.60 & 0.34 & 0.20 & -0.77 & - & - \\
\hline
\end{tabular}


Data in Table 4 revealed that $\mathrm{G}$ $\mathrm{x} E$ (linear) was not significant and had low portion of the $\mathrm{G} \times \mathrm{E}$ interaction when compared to the environment linear mean of squares for grain yield and the other studied traits. Hence, only the deviation mean square was considered important.

Significant pooled deviation were detected for number of days to $50 \%$ silking, plant height and grain yield. Significant pooled deviation clear that performance of different hybrids fluctuated significantly from their respective linear path of response to environments.

Therefore, on analysis the individual hybrid fluctuation from linearity, it becomes notice that all hybrids possessed significant variance, except H10 and H11 for grain yield. Theses hybrid had small and insignificant deviation from linearity and would be stable according to Paroda and Hays
(1971), and Line et al. (1986). These results are in agreement with Soliman (2006), Al-Otayk (2010) and Hassan et al. (2013).

The hybrids H4, H6, H10, H11 and $\mathrm{H} 12$ for number of days to $50 \%$ silking, and $\mathrm{H} 1, \mathrm{H} 2, \mathrm{H} 5$ and $\mathrm{H} 9$ for plant height fluctuated significantly, other varieties did not they remained by and large, close to linear response.

Stability parameters according to Eberhart and Russell (1966) were used. Regression coefficient $\left(b_{i}\right)$ for each hybrid and deviations from regression $\left(\mathrm{S}_{\mathrm{di}}^{2}\right)$ are presented in Tables 5 and 6 . A regression coefficient $\left(b_{i}\right)$ close to 1.0 coupled with small value of $\left(S_{\mathrm{di}}^{2}\right)$ indicates average stability. Regression values above 1.0 indicate genotypes with higher sensitivity to environmental change and greater specificity of adaptability to high yielding environments. 
Table (4): Stability analysis for grain yield, number of days to $50 \%$ silking, plant and ear height of 13 single cross hybrids evaluated at 5 different environments, during 2013 growing season.

\begin{tabular}{|c|c|c|c|c|c|}
\hline S.O.V & d.f. & $\begin{array}{c}\text { Days to } \\
50 \% \text { silking }\end{array}$ & $\begin{array}{c}\text { Plant } \\
\text { height }(\mathrm{cm})\end{array}$ & $\begin{array}{l}\text { Ear height } \\
\text { (cm) }\end{array}$ & $\begin{array}{c}\text { Grain yield } \\
\left(\mathrm{kg} \mathrm{plot}^{-1}\right)\end{array}$ \\
\hline Environments & 4 & $80.807 * *$ & $21282.71^{* *}$ & $10545.45^{* *}$ & $23.67 * *$ \\
\hline Genotypes & 12 & $178.32 * *$ & $6859.76^{* *}$ & $3317.74 * *$ & $4.17 * *$ \\
\hline $\mathbf{G} \times \mathbf{E}$ & 48 & $3.037 * *$ & $421.49 * *$ & $173.68 * *$ & $0.73 * *$ \\
\hline$E+(G \times E)$ & 52 & 13.29 & $2025.94 * *$ & $968.98 * *$ & $2.51 * *$ \\
\hline E (linear) & 1 & $234.05^{* *}$ & $85121.46^{* *}$ & $42116.02 * *$ & $94.98 * *$ \\
\hline G x E (linear) & 12 & 10.97 & 614.49 & 283.56 & 1.20 \\
\hline Pooled deviation & 39 & $8.35 * *$ & $329.58 * *$ & 124.82 & $0.54 * *$ \\
\hline H1 & 3 & 2.31 & $1060.12 * *$ & $314.32 *$ & $0.41 *$ \\
\hline H2 & 3 & 1.62 & $1377.02 * *$ & 95.27 & $0.80 * *$ \\
\hline H3 & 3 & 2.45 & 140.25 & 197.62 & $0.47 *$ \\
\hline H4 & 3 & $6.08 * *$ & 63.00 & 113.45 & $0.85 * *$ \\
\hline H5 & 3 & 1.37 & $447.82 *$ & 39.42 & $0.82 * *$ \\
\hline H6 & 3 & $5.81 * *$ & 162.88 & $278.62 *$ & $0.54 * *$ \\
\hline H7 & 3 & 2.08 & 12.35 & 94.95 & $0.52 *$ \\
\hline H8 & 3 & 1.34 & 108.53 & 41.27 & $0.36^{*}$ \\
\hline H9 & 3 & 1.99 & $532.73 *$ & 132.66 & $0.39 *$ \\
\hline H10 & 3 & $10.90 * *$ & 169.95 & 27.86 & 0.11 \\
\hline H11 & 3 & $10.71 * *$ & 62.55 & 56.57 & 0.08 \\
\hline H12 & 3 & $5.81 * *$ & 113.05 & 174.78 & $0.67 * *$ \\
\hline H13 & 3 & 2.70 & 34.26 & 55.87 & $1.02 * *$ \\
\hline Pooled error & 180 & 1.42 & 146.36 & 98.32 & 0.13 \\
\hline
\end{tabular}

*, ** indicate significant differences at 0.05 and 0.01 levels of probability, respectively. 
A regression coefficient below 1.0 provides a measurement of greater resistance to environmental change and thus increases the specificity of adaptability to low yielding environments.

Regarding number of days to $50 \%$ silking (Table 5), the most stable hybrids with the lowest $\left(\mathrm{S}_{\mathrm{di}}^{2}\right)$ value were $\mathrm{H} 5$ ranked first, $\mathrm{H} 8$ ranked second, $\mathrm{H} 2$ ranked third, $\mathrm{H} 9$ ranked fourth, $\mathrm{H} 7$ ranked fifth. If the number of days to $50 \%$ silking $(\overline{\mathrm{X}})$ (towards earliness), regression coefficient value $\left(b_{i}\right)$ and the deviation from the regression $\left(\mathrm{S}_{\mathrm{di}}^{2}\right)$ are considered together, then the most stable hybrid would be $\mathrm{H} 5$ with number of days to $50 \%$ silking $(\overline{\mathrm{X}})=57.50$ day, $b_{i}=1.082$ close to one and the lowest $\mathrm{S}_{\mathrm{di}}^{2}$ value $(-0.05)$ followed by $\mathrm{H} 4$ with number of days to $50 \%$ silking $(\overline{\mathrm{X}})=57.30$ day, $\mathrm{b}_{\mathrm{i}}=0.962$ close to one and the $\left(\mathrm{S}_{\mathrm{di}}^{2}\right)$ value $=4.66$.

For plant height (Table 5), when average plant height $(\overline{\mathrm{X}})$ (towards shortness), regression coefficient value $\left(b_{i}\right)$ and the deviation from the regression $\left(\mathrm{S}_{\mathrm{di}}^{2}\right)$ are considered together, therefore the most stable hybrid would be $\mathrm{H} 6$ with $(\overline{\mathrm{X}})=224.50$ $\mathrm{cm}$ ranked the first, $\mathrm{b}_{\mathrm{i}}=0.822,\left(\mathrm{~S}_{\mathrm{di}}^{2}\right)$ value $=16.52$ and not significant. The hybrid $\mathrm{H} 8$ ranked the second with average plant height $224.75 \mathrm{~cm}$, bi $=$ 0.872 and $\mathrm{S}_{\text {di }}^{2}$ value $=-37.83$. Hybrid $\mathrm{H} 4$ ranked the third with plant height $233.40 \mathrm{~cm}, \mathrm{bi}=1.096$ and $\mathrm{S}_{\mathrm{di}}^{2}$ value $=-83.36$. Hybrid $\mathrm{H} 11$ ranked the fourth with plant height $234.00 \mathrm{~cm}$, bi $=0.822$ and $\left(\mathrm{S}_{\mathrm{di}}^{2}\right)$ value $=-83.81$.

For ear height (Table 6), when ear height mean $(\overline{\mathrm{X}})$, regression coefficient value $\left(b_{i}\right)$ are considered together, then the most stable hybrid would be $\mathrm{H} 4$ with $(\overline{\mathrm{X}})=117.05 \mathrm{~cm}$ ranked the first, $b i=1.015$ close to unity, $\left(\mathrm{S}_{\mathrm{di}}^{2}\right)$ value $=15.13$ and not significant. 
Table (5): Stability parameters for number of days to $50 \%$ silking and plant height $(\mathrm{cm})$ of 13 single cross hybrids evaluated under different environments, during 2013 growing season.

\begin{tabular}{|c|c|c|c|c|c|c|c|c|c|c|c|c|c|c|c|c|}
\hline \multirow{2}{*}{ Hybrid } & \multicolumn{8}{|c|}{ Number of days to $50 \%$ silking } & \multicolumn{8}{|c|}{ Plant height (cm) } \\
\hline & Mean & Rank & $\mathbf{b}_{\mathbf{i}}$ & Rank & $\mathbf{S}_{\mathrm{di}}^{2}$ & Rank & $\mathbf{w}_{\mathbf{i} \%}$ & Rank & Mean 1 & Rank & $\mathbf{b}_{\mathbf{i}}$ & Rank & $\mathbf{S}_{\mathrm{di}}^{2}$ & Rank & $\mathbf{w}_{\mathbf{i} \%}$ & Rank \\
\hline H1 & 64.30 & 12 & $1.670 *$ & 8 & 0.89 & 7 & 4.39 & 6 & 258.60 & 10 & $1.407 *$ & 12 & $913.76^{* *}$ & 12 & 21.14 & 13 \\
\hline H2 & 65.00 & 13 & 0.897 & 4 & 0.20 & 3 & 3.54 & 3 & 285.80 & 13 & 0.864 & 6 & $1230.66 * *$ & 13 & 21.14 & 12 \\
\hline H3 & 60.40 & 6 & $2.056 *$ & 12 & 1.03 & 6 & 8.68 & 9 & 235.00 & 6 & $0.261 *$ & 13 & -6.11 & 7 & 19.91 & 11 \\
\hline H4 & 57.30 & 2 & 0.962 & 2 & $4.66 * *$ & 11 & 3.84 & 5 & 233.40 & 4 & 1.096 & 4 & -83.36 & 4 & 1.23 & 2 \\
\hline H5 & 57.50 & 3 & 1.082 & 3 & -0.05 & 1 & 2.55 & 1 & 262.35 & 11 & 0.927 & 2 & $301.46^{*}$ & 10 & 6.86 & 9 \\
\hline H6 & 58.00 & 5 & 1.573 & 7 & $4.39 * *$ & 10 & 10.22 & 10 & 224.50 & 1 & 0.872 & 5 & 16.52 & 8 & 2.97 & 6 \\
\hline H7 & 57.50 & 4 & $1.846^{*}$ & 11 & 0.66 & 5 & 4.54 & 7 & 257.00 & 9 & 1.026 & 1 & -134.01 & 1 & 1.09 & 1 \\
\hline H8 & 56.40 & 1 & $1.808 *$ & 10 & -0.08 & 2 & 3.70 & 4 & 224.75 & 2 & 0.817 & 7 & -37.83 & 5 & 2.72 & 4 \\
\hline H9 & 61.55 & 7 & $1.686^{*}$ & 9 & 0.57 & 4 & 2.70 & 2 & 231.35 & 3 & $1.273 *$ & 10 & $386.37^{*}$ & 11 & 10.05 & 10 \\
\hline H10 & 62.65 & 10 & $2.257 *$ & 13 & $9.48 * *$ & 13 & 20.82 & 13 & 249.05 & 8 & 0.910 & 3 & 23.59 & 9 & 2.81 & 5 \\
\hline H11 & 62.55 & 8 & 1.543 & 6 & $9.29 * *$ & 12 & 20.66 & 12 & 234.00 & 5 & 0.822 & 8 & -83.81 & 3 & 1.98 & 3 \\
\hline H12 & 64.30 & 11 & 1.518 & 5 & $4.39 * *$ & 9 & 11.42 & 11 & 265.65 & 12 & $1.227 *$ & 9 & -33.31 & 6 & 3.34 & 7 \\
\hline H13 & 62.55 & 9 & 0.960 & 1 & 1.28 & 8 & 5.37 & 8 & 239.85 & 7 & $1.363 *$ & 11 & -112.1 & 2 & 4.76 & 8 \\
\hline
\end{tabular}

$*, * *$ indicate significant differences at 0.05 and 0.01 levels of probability, respectively. 
Hybrid $\mathrm{H} 9$ ranked the second with ear height $128.55 \mathrm{~cm}, b_{i}=0.980$ and $\left(\mathrm{S}_{\mathrm{di}}^{2}\right)$ value $=34.34$. Hybrid $\mathrm{H} 7$ ranked the third with ear height $132.20 \mathrm{~cm}, b_{i}=1.074$ and $\mathrm{S}_{\text {di }}^{2}$ value $=$ -3.37 .

For grain yield (Table 6) the most stable hybrids with the lowest $\left(\mathrm{S}_{\mathrm{di}}^{2}\right)$ values were H11 ranked first, $\mathrm{H} 10$ ranked second, $\mathrm{H} 8$ ranked third, $\mathrm{H} 9$ ranked forth and $\mathrm{H} 1$ ranked fifth. The most unstable hybrids with the highest $\mathrm{S}_{\mathrm{di}}^{2}$ values were $\mathrm{H} 13, \mathrm{H} 4$ and H5. If the mean yield $(\overline{\mathrm{X}})$, regression coefficient value $\left(b_{i}\right)$ and the deviation from the regression $\mathrm{S}_{\mathrm{di}}^{2}$ are considered together, then the most stable hybrid would be $\mathrm{H} 2$ with an average grain yield $\overline{\mathrm{X}}=5.15 \mathrm{~kg} \mathrm{plot}^{-1}$ ranked first, $b_{i}=1.038$ close to one and the $\left(S_{d i}^{2}\right)=0.67$ followed by H9 with an average grain yield $4.69 \mathrm{~kg} \mathrm{plot}^{-}{ }^{1}$ and $\mathrm{S}_{\mathrm{di}}{ }_{\mathrm{i}}=0.26$ ranked fourth. The relationship between grain yield and coefficient of regression $\left(b_{i}\right)$ for the 13 tested hybrids are shown at Fig 1.

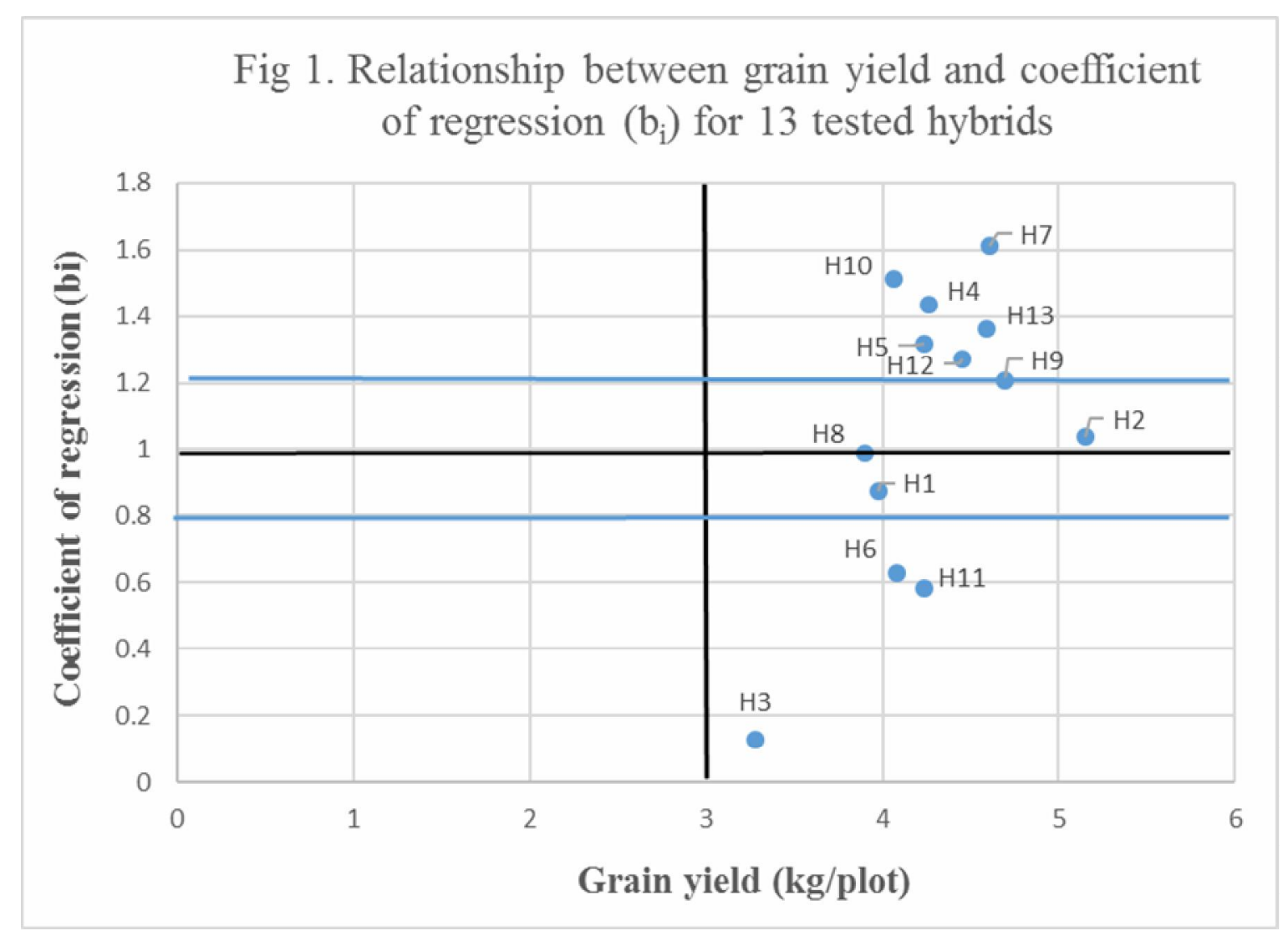


Table (6): Stability parameters for ear height and grain yield $\left(\mathrm{kg} \mathrm{plot}^{-1}\right)$ of 13 single cross hybrids evaluated under different environments, during 2013 growing season.

\begin{tabular}{|c|c|c|c|c|c|c|c|c|c|c|c|c|c|c|c|c|}
\hline \multirow{2}{*}{ Hybrid } & \multicolumn{8}{|c|}{ Ear height (cm) } & \multicolumn{8}{|c|}{ Grain yield (kg plot $\left.{ }^{-1}\right)$} \\
\hline & Mean & Rank & $\mathbf{b}_{\mathbf{i}}$ & Rank & $\mathbf{S}_{\mathrm{di}}^{2}$ & Rank & $\mathbf{w}_{\mathbf{i} \%}$ & Rank & Mean & Rank & $\mathbf{b}_{\mathbf{i}}$ & Rank & $\mathbf{S}_{\mathrm{di}}^{2}$ & Rank & $\mathbf{W}_{\mathbf{i} \%}$ & Rank \\
\hline H1 & 147.55 & 12 & 1.012 & 1 & $216.00 *$ & 13 & 11.11 & 11 & 3.98 & 12 & 0.874 & 3 & $0.28^{*}$ & 5 & 4.01 & 3 \\
\hline H2 & 156.35 & 13 & $1.732 *$ & 13 & -3.05 & 7 & 24.03 & 13 & 5.15 & 1 & 1.038 & 2 & $0.67 * *$ & 10 & 6.75 & 6 \\
\hline H3 & 124.65 & 4 & $0.479 *$ & 12 & 99.30 & 11 & 17.23 & 12 & 3.28 & 13 & $0.128 *$ & 13 & $0.34^{*}$ & 6 & 20.83 & 13 \\
\hline H4 & 117.05 & 3 & 1.015 & 2 & 15.13 & 8 & 4.03 & 5 & 4.26 & 6 & $1.433 *$ & 10 & $0.72 * *$ & 12 & 10.19 & 10 \\
\hline H5 & 137.80 & 8 & 0.842 & 8 & -58.9 & 2 & 2.35 & 3 & 4.24 & 8 & $1.317^{*}$ & 6 & $0.69^{* *}$ & 11 & 8.34 & 9 \\
\hline H6 & 116.30 & 2 & 0.920 & 5 & $180.30 *$ & 12 & 10.02 & 10 & 4.08 & 10 & $0.630^{*}$ & 8 & $0.41 * *$ & 8 & 8.06 & 8 \\
\hline H7 & 132.20 & 6 & 1.074 & 4 & -3.37 & 6 & 3.47 & 4 & 4.61 & 3 & $1.614 *$ & 12 & $0.39 *$ & 7 & 10.85 & 12 \\
\hline H8 & 115.55 & 1 & $0.738^{*}$ & 11 & -57.05 & 3 & 4.05 & 6 & 3.90 & 9 & 0.987 & 1 & $0.23 *$ & 3 & 3.07 & 2 \\
\hline H9 & 128.55 & 5 & 0.980 & 3 & 34.34 & 9 & 7.63 & 8 & 4.69 & 2 & 1.208 & 4 & $0.26^{*}$ & 4 & 4.40 & 4 \\
\hline H10 & 139.20 & 9 & 0.858 & 7 & -70.46 & 1 & 1.76 & 1 & 4.06 & 11 & $1.510 *$ & 11 & -0.02 & 2 & 1.13 & 1 \\
\hline H11 & 136.60 & 7 & 0.904 & 6 & -41.75 & 5 & 2.33 & 2 & 4.24 & 7 & $0.585^{*}$ & 9 & -0.05 & 1 & 5.02 & 5 \\
\hline H12 & 146.80 & 11 & 1.185 & 9 & 76.46 & 10 & 7.86 & 9 & 4.45 & 5 & 1.270 & 5 & $0.54 * *$ & 9 & 6.69 & 7 \\
\hline H13 & 140.05 & 10 & $1.240^{*}$ & 10 & -42.45 & 4 & 4.14 & 7 & 4.59 & 4 & $1.363 *$ & 7 & $0.89 * *$ & 13 & 10.66 & 11 \\
\hline
\end{tabular}

$*, * *$ indicate significant differences at 0.05 and 0.01 levels of probability, respectively. 
Wricke's ecovalence was determined for each of the 13 hybrids evaluated at 5 environments and are presented in Tables 5 and 6.

Regarding number of days to $50 \%$ silking (Table 5), the most stable hybrids which possessed low ecovalence value were $\mathrm{H} 5, \mathrm{H} 9$ and $\mathrm{H} 2$. This hybrid did not have the best rank for earliness except, $\mathrm{H} 5$, which ranked the $3^{\text {rd }}$ with 57.50 days. The most unstable hybrids according to ecovalence method were $\mathrm{H} 10$ and H11. These hybrids were ranked $8^{\text {th }}$ and $10^{\text {th }}$ for number of days to $50 \%$ silking.

For plant height (Table 5), the most stable hybrids according to ecovalence model were $\mathrm{H} 7, \mathrm{H} 4, \mathrm{H} 5$ and H2. These hybrids ranked the $9^{\text {th }}, 4^{\text {th }}$, $5^{\text {th }}$ and $2^{\text {nd }}$ for plant height, respectively. On the other hand, the most unstable hybrid were $\mathrm{H} 1$ and $\mathrm{H} 2$.

Concerning ear height (Table 6) the most stable hybrid were H10, H11, H5 and H7. These hybrids were not the best rank for low ear height and it is rank were $9^{\text {th }}, 7$ th, $8^{\text {th }}$, and $6^{\text {th }}$ .The most unstable hybrids according to ecovalence model were $\mathrm{H} 2$ and H3.

For grain yield (Table 6) the most stable hybrids according to the ecovalence method of Wricke (1962) were $\mathrm{H} 10, \mathrm{H} 8, \mathrm{H} 1, \mathrm{H} 9$. These hybrids did not gave the best rank for grain yield, except $\mathrm{H} 9$, which possessed the first rank for grain yield with $5.15 \mathrm{~kg}$ plote $^{-1}$ and it is consider promising hybrid for stability and may be recommended to be released as stable high yielding hybrid under a wide range of environmental conditions. The most unstable hybrids according the ecovalence method were $\mathrm{H} 3$ and
H7 these hybrids were ranked $13^{\text {th }}$ and $3^{\text {rd }}$ for grain yield, respectively.

\section{Conclussion:}

According to Eberhart and Russell model the most stable hybrid would be $\mathrm{H} 2$ and $\mathrm{H} 9$. The most stable hybrids according to the ecovalence method were $\mathrm{H} 10, \mathrm{H} 8, \mathrm{H} 1$, and $\mathrm{H} 9$. These hybrids were not the best ranked for grain yield, except H9, which possessed the first rank for grain yield with $5.15 \mathrm{~kg} \mathrm{plote}^{-1}$ (Plot size is $9.6 \mathrm{~m}^{2}$ ) and is considered as a promising hybrid for stability.

Acknowledgment: My sincere thanks go to all the staff and technicians of maize research section, field crops research institute for taking care of the experiment to generate this data. I also thank my colleagues at Mallawy Agricultural Research station for their helping and critical review of the manuscript.

\section{References:}

Abd El-Moula, M.A., 2011. Yield Stability and GenotypeEnvironment interaction of Some Promising yellow Maize Hybrids. Egypt J. plant Breed. 15(4): 63-74.

Al-Otayk, 2010. Performance of yield stability of wheat genotypes under high stress environments of the central region of Saudi Arabia, Met. Env. Arid Land Agric. Sci. 21: 81-92.

Eberhart, S.A. and W.A. Russell, 1966. Stability parameters for comparing varieties. Crop Sci., 6: 36-40.

Freeman, G.H. and J.M. Perkins, 1971. Environmental and genotype- environmental components of variability. VIII. Relation between genotypes grown 
in different environments and measures of these environments. Heredity, 27: 15-23.

Freeman, G.H., 1973. Statistical methods for the analysis of genotype-environment interactions. Heredity, 31: 339-354.

Hallauer, A.R. and J.B. Miranda Filho. 1988. Quantitative Genetics in Maize Breeding. 2nd ed. Iowa State University Press., Ames, IA.

Hassan, M.S., G.I.A. Mohamed and R.A.R. El-Said, 2013. Stability analysis for grain yield and its components of some Durum wheat genoypes (Triticum durum L.) under different environments. Asian J. Crop Sci., 5(2): 179-189.

Heinrich, G.M., C.A. Francis and J.D. Eastin, 1983.Stability of grain sorghum yield components across divers environments. Crop Sci., 23: 209-212.

Ibrahim, M.S.A., O.O. El-Nagouly and M.I. Salama, 1984. OnFarm evaluation for yield stability of maize varieties in Egypt. Administrative Report. Proc. EMCIP, 1: 103-112.
Lin, C.S., M.R. Binns and L.P. Lefkovitch, 1986. Stability analysis: Where do we stand? Crop Sci. 26:894-900.

Paroda, R.S. and J.D. Hayes, 1971. An investigation of genotypeenvironment interaction for rate of ear emergence in spring barley. Heredity 26: 157-175.

Ragheb, M.M.A., A.A. Bedeer, A. Sh. Gouda, Sh.F. Abo-El-Saad, and A.A. Abdel-Aziz, 1993. Phenotypic stability parameters for grain yield and other agronomic characters of white maize hybrids under different environmental conditions. Zagazig J. Agric. Res., 20(5): 1447-1461.

Soliman, M.S.M., 2006. Stability and environmental interaction of some promising yellow Maize Genotypes. Res. J. Agric. \& Biol. Sci., 2(6): 249-255.

Steel, R.G.D. and Torrie, 1980. Principles and Procedures of Statistic. McGraw-Hill Book Company, New York, Toronto and London.

Wricke, G., 1962. Über eine Method zur Erfassung der Ökologischen Streubreite in Feldversuchen. Z. Pflanzenzuchtg, 47: 92-96. 


\section{الآداء وتحليل الثبات لبعض هجن الذرة الثامية الصفراء خالا عبد الحفيظ محمد ابر اهيم \\ قسم المحاصيل - كلية الزراعة بالو ادى الجديد - جامعة أسيوط}

اجريت هذه الدراسة خلال الموسم الصيفى ب ا ـ ب فى خمسة مو اقع وهى محطات البحوث الزر اعية بسخا و الجميزة وسدس وملوى و النوبارية التنابعة لمركز البحوث الزر اعيــة- مــصر. كان الهدف من الدر اسة تقدير ثبات انتاجية محصول الحبوب وبعض الصفات الخضرية الاخرى

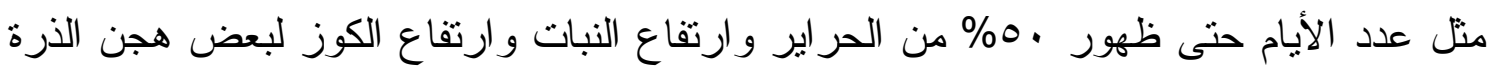

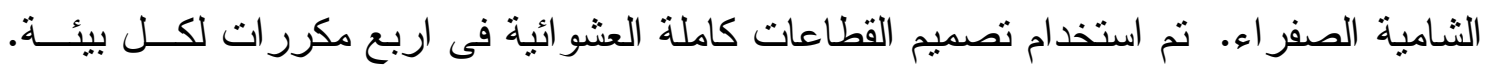

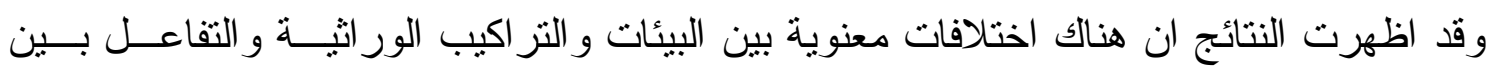

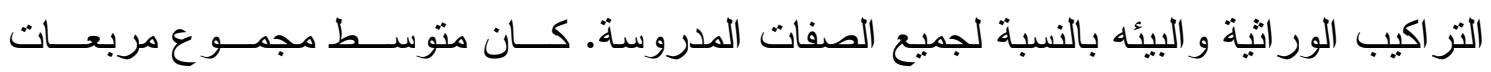

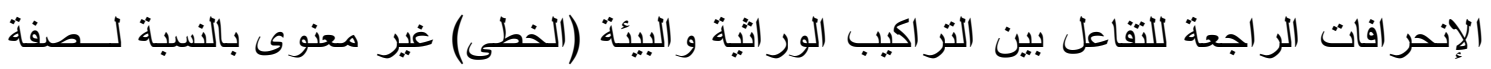

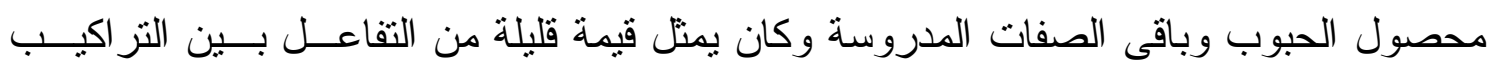

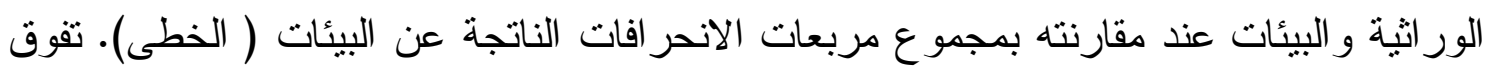

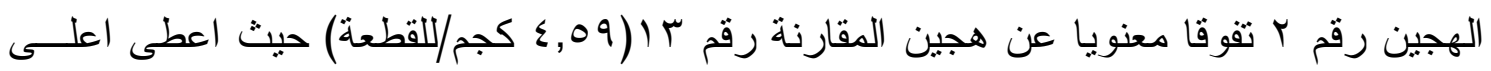

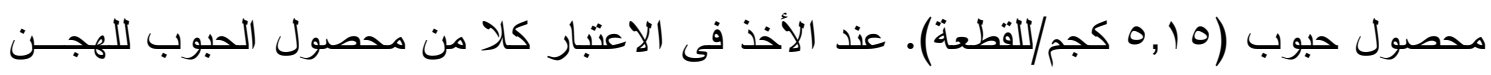

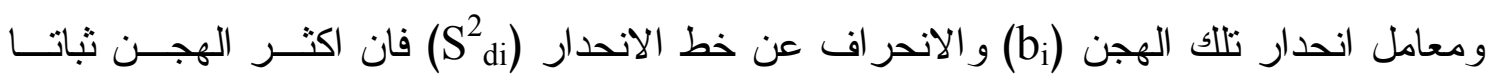
بالنسبة لمحصول الحبوب هما الهجين الفردى سخا (H2) و الهجين الفردى (H9). امــا بالنسبة لمعامل التكافؤ البيئى (Wi ) فان اكثر الهجن ثباتا بالنسبة لصفة محصول الحبوب هـــ الهجــن

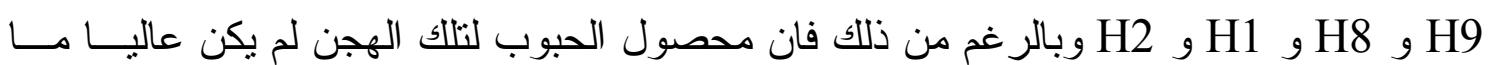
عدا الهجين الفردى H2 حيث امتلك قدرة محصولية عالية (0, 10 كجم/قطعة) ويعتبر من الهجن الو اعدة من حيث الثبات بالنسبة لصفة محصول الحبوب. 